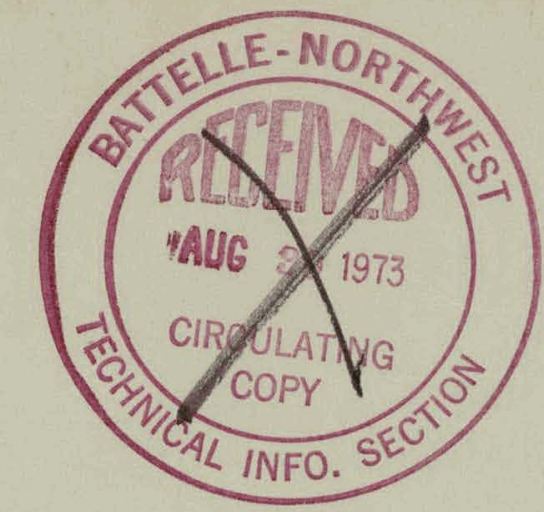

BNWL-B-274

\title{
INTERIM REPORT:
}

THE FRACTIONAL AIRBORNE RELEASE

OF DISSOLVED RADIOACTIVE MATERIALS

DURING THE COMBUSTION OF 30 PERCENT

NORMAL TRIBUTYL PHOSPHATE

IN A KEROSINE-TYPE DILUENT

\section{. \\ Battelle}

Pacific Northwest Laboratories

Richland, Washington 99352

\section{JUNE 1973}

This report is intended primarily for internal use by the sponsoring organization and Battelle.

Prepared for the U.S. Atomic Energy

Commission under Contract AT(45-1):1830 


\section{DISCLAIMER}

This report was prepared as an account of work sponsored by an agency of the United States Government. Neither the United States Government nor any agency Thereof, nor any of their employees, makes any warranty, express or implied, or assumes any legal liability or responsibility for the accuracy, completeness, or usefulness of any information, apparatus, product, or process disclosed, or represents that its use would not infringe privately owned rights. Reference herein to any specific commercial product, process, or service by trade name, trademark, manufacturer, or otherwise does not necessarily constitute or imply its endorsement, recommendation, or favoring by the United States Government or any agency thereof. The views and opinions of authors expressed herein do not necessarily state or reflect those of the United States Government or any agency thereof. 


\section{DISCLAIMER}

Portions of this document may be illegible in electronic image products. Images are produced from the best available original document. 
NOTICE

The report was prepared as an account of work sponsored by the United States Government. Neither the United States nor the United States Atomic Energy Commission, nor any of their employees. nor any of thcir contrartnrs subcontractors, or their employees, makes any warranty, express or implied, or assurnes any legal liability or responsibility for the accuracy, completencss or usefulness of any information, apparatus, product or process disclosed, or represents that its use would not infringe privately owned rights.

PACIFIC NORTHWEST LABORATORY

operated by

BATTELLE

for the

U.S. ATOMIC ENERGY COMMISSION

Under Contract AT(45-1)-1830

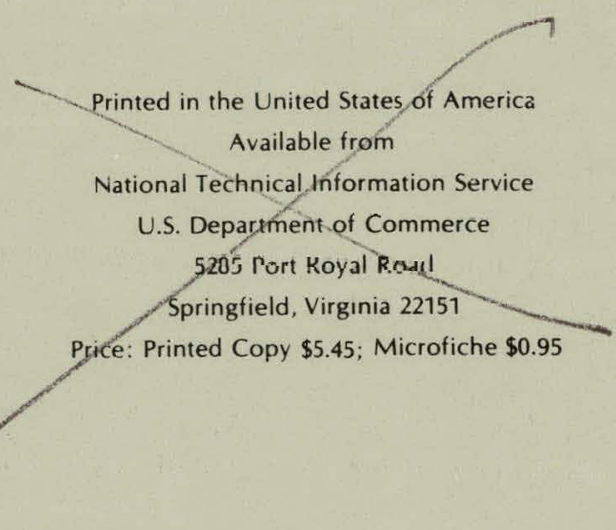




\section{INTERIM REPORT:}

THE FRACTIONAL AIRBORNE RELEASE OF DISSOLVED RADIOACTIVE MATERIALS DURING THE COMBUSTION OF 30 PERCENT NORMAL

TRIBUTYL PHOSPHATE IN A KEROSINE-TYPE DILUENT

J. Mishima

L.C. Schwendiman

Atmospheric Analysis Section
ATMOSPHERIC SCIENCES DEPARTMENT

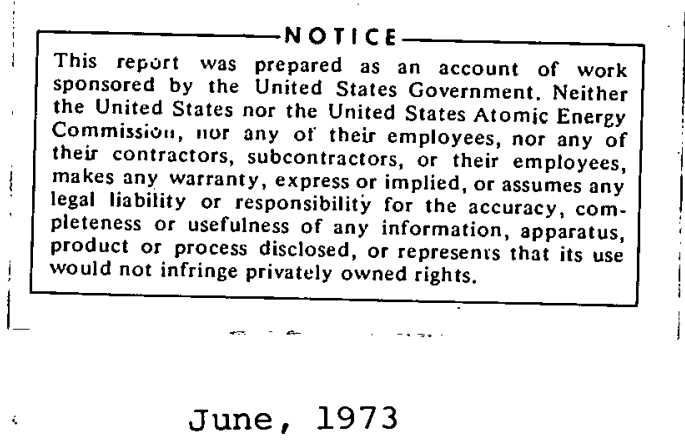

\section{BATTELLE-NORTHWEST}

Battelle, Pacific Northwest Laboratories Richland, washington 


\section{TABLE OF CONTENTS}

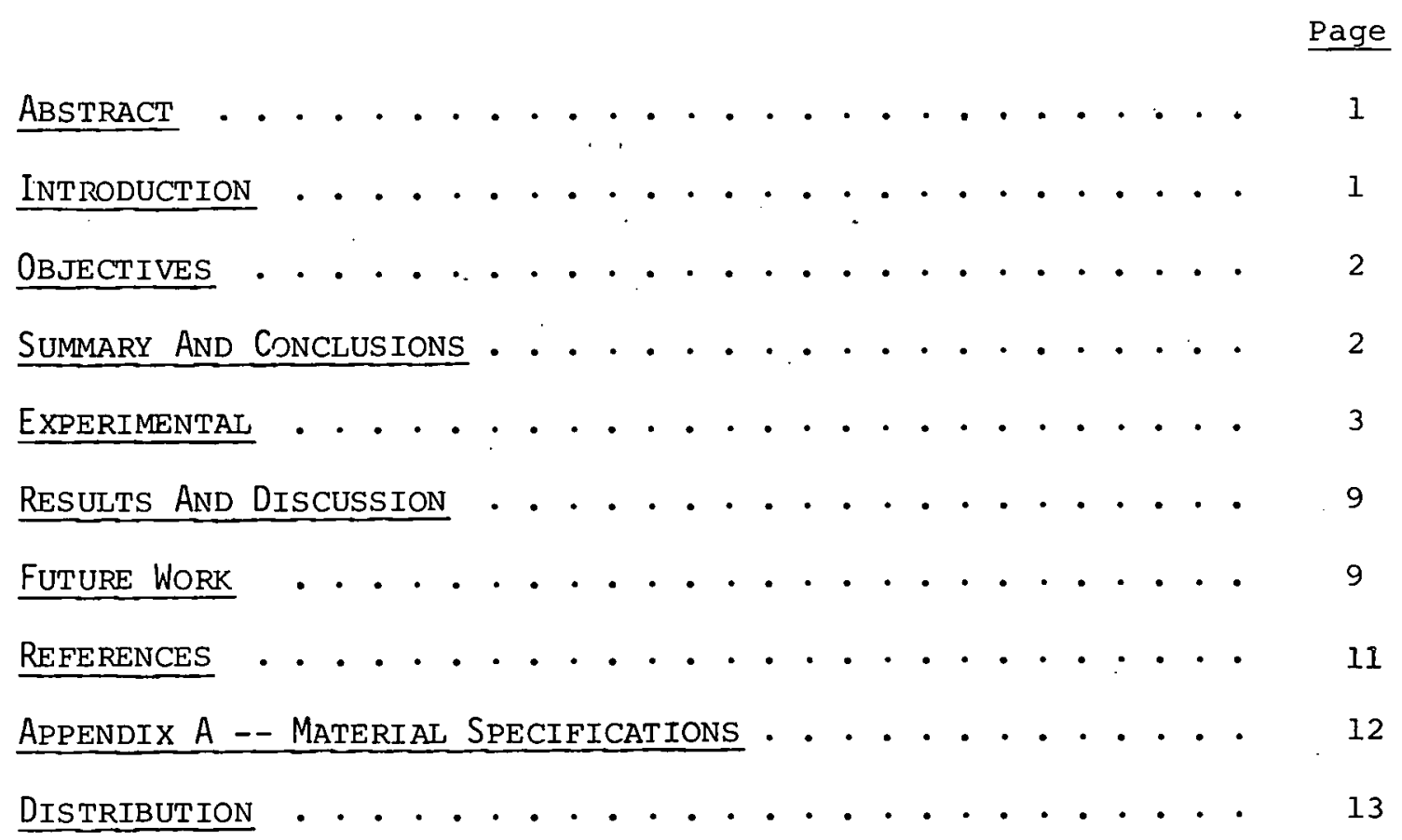




\section{LIST OF FIGURES}

Page

Figure la -- Apparatus Used in Measuring Fractional Airborne Release ...................... 4

Figure $1 \mathrm{~b}$-- Schematic Diagram of Experimental Apparatus ...... 5

Figure 2 -- Heating Solvent with Propane Torch ........... 7

Figure $3^{--}$Airborne Particles and Iodine Col.lector ........ 8 
INTERIM REPORT :

THE FRACTIONAL AIRBORNE RELEASE OF DISSOLVED. RADIOACTIVE

MATERIALS DURING THE COMBUSTION OF 30 PERCENT NORMAL. TRIBUTYL PHOSPHATE IN A KEROSINE-TYPE DILUENT

\begin{abstract}
$\underline{\text { ABSTRACT }}$
Laboratory scale experiments were performed to indicate the fraction of uranium and certain fission products made airborme during a fire involving contaminated, flammable solvents. Small quantities of $30 \%$ normal tributyl phosphate in a kerosine diluent containing Purex processrepresentative concentrations of selected radioactive elements -- uranium, cesium, zirconium, cerium, and iodine -were burned in an upsweep of air and the fractional release measured. Nominal velocities in the 2.7 inch stainless steel chimney exhausting gases from the combustion vessel were 25 and 59 feet per minute. Sixty-five percent of the iodine was released when the liquid bumed in a selfsustaining flame up to the point of self-extinguishment. Further heating to a char resulted in a total release of about $83 \%$. One percent or less of other elements was released even when the vessel was heated externally with a propane torch following the self-sustaining buming period.
\end{abstract}

\title{
INTRODUCTION
}

As nuclear reactors provide an increasing portion of the nation's growing eniryy dellduls, the behavior of radioactive materials contained in fuel during various parts of the fuel cycle is of concern. An important segment of the cycle is the reprocessing step in which fissile fuel constituents are reclaimed through chemical separation steps. Liquid-liquid extraction using normal tributyl phosphate (TBP) in a kerosine diluent, normal paraffin hydrocarbon (NPH) is commonly used in separating fissile and fertile materials from waste fission products generated in reactors.

In a typical Purex fuel reprocessing plant uranium and plutonium are decontaminated, separated and purified by solvent extraction. In this process, the elements of valence IV are relatively extractable while elements of valence III are relatively unextractable. Nitric acid is used as a salting agent. Primary separation of the uranium and plutonium from the radioactive waste occurs in the initial cycle of the process -- co-decontamination. Greater than 
99.9 percent of the fission products are removed into the aqueous waste stream. The uranium, plutonium and remaining fission products are found in the organic product stream. This organic phase contains the highest concentration of total radioactive material found in an organic phase in the Purex process. Among the radioactive materials of interest in separation processes are ${ }^{137} \mathrm{Cs},{ }^{131} \mathrm{~T}$, $144 \mathrm{Ce}-\mathrm{Pr},{ }^{95} \mathrm{Zr}-\mathrm{Nb} .{ }^{[1]}$ Many other fission products are present; those named. are representative of chemically-similar groupings of the spectrum of the fission products present.

The organic solvent, 30 percent TBP in kerosine, is of limited flammability. TBP has a flash point of $295^{\circ} \mathrm{F}, \mathrm{Class}$ I flammability, and kerosine has a flash point of $100^{\circ} \mathrm{F}$, Class 2 flammability. [2] There are some indications that the kerosine under process conditions of saturation with water is flammable over a limited range of temperature. [3] Low probability fire-initiating events may nevertheless occur and lead to combustible vapor formation which sustains burning over extended periods. Work earlier reported describes large scale fire characteristics. [4]

\section{OBJECTIVES}

The objective of this study was to measure the fractional airborne release of selected radioactive isotopes during the burning of 30 percent $n-T B P$ in kerosine containing quantities of these isotopes found in the organic product from the co-decontamination cycle of the Purex process.

\section{SUMmaRY AND CONCLUSIONS}

Twenty-one laboratory scale experiments were performed to measure the fractional airborne release of uranium and radioactive isotope-traced cesium, cerium, zirconium and iodine during the combustion of 30 percent n-TBP in NPH solution simulating the organic product from the Purex co-decontamination cycle. Twenty-five ml of a prepared organic solvent solution was burned in an upsweep of air. The quantity of uranium and traced isotopes airborne in the combustion products and in the residues deposited on the chimney was measured.

A significant quantity of ${ }^{131}$ I was released during the period of the self-. susldilling fire, (65\%). About 18 percent more was released when external heat 
was applied to char any residue, giving a total release of about 83 percent. One percent or less of the other isotopes $\left({ }^{137} \mathrm{Cs},{ }^{144} \mathrm{Ce}-\mathrm{Pr},{ }^{95} \mathrm{Zr}-\mathrm{Nb}\right.$, and uranium) were released in either mode of combustion.

\section{EXPERIMENTAL}

As part of a larger study of "Fires in Caves, Canyons and Hot-Cells" $[4,5,6]$ twenty-one laboratory scale experiments were performed to measure the fractional airbornc release of representative substances dissolved in 30 percent $n-T B P$ in normal paraffin hydrocarbon. The specifications for this material is shown in Appendix A. Small volumes of organic solvent containing a Purex process-representative amount of uranium and fractional part per million concentrations of cesium, cerium, zirconium, iodine, and ruthenium were burned in a $50 \mathrm{ml}$ beaker. The selected fission products (other than ruthenium) were traced with radioactive isotopes. The uranium was extracted into the solvent from a $6 \underline{N}$ nitric acid solution and thus the organic phase was in equilibrium with an aqueous phase. Other elements were placed in solution by the addition of small volumes of concentrated aqueous solutions. A single batch of solvent with uranium and fission isotopes was prepared at the start of the program and used in all subsequent work.

A $50 \mathrm{ml}$ beaker containing $25 \mathrm{ml}$ of the organic solvent was preheated prior to ignition. Preliminary studies indicated temperature in excess of $90^{\circ} \mathrm{C}$ was required before a suffieient concentration of vapors was generated to sustain combustion. The liquid was heated to boiling within a few minutes with a small heating unit.

As soon as the solvent was sufficiently warm, the beaker was placed on a support and the vapors ignited with a propane torch. A 2.7 inch diameter, stainless steel chimney was supported over the beaker. One or two cu. ft. per min. of air was drawn through the chimney to sweep materials emitted to a filter sealing the upper end of the chimney. A loose pad of glass fiber (insulating material) was placed in front of the filter to prevent clogging of the filter by soot during the experiment. The apparatus is shown in Figures la, and $1 b$.

Experiment.s were concluded in two ways -- self extinguishment or heating with a separate heat source to dryncss. Once ignited, the solvent continued to generate sufficient vapor to continue burning. Typical liquid temperatures 


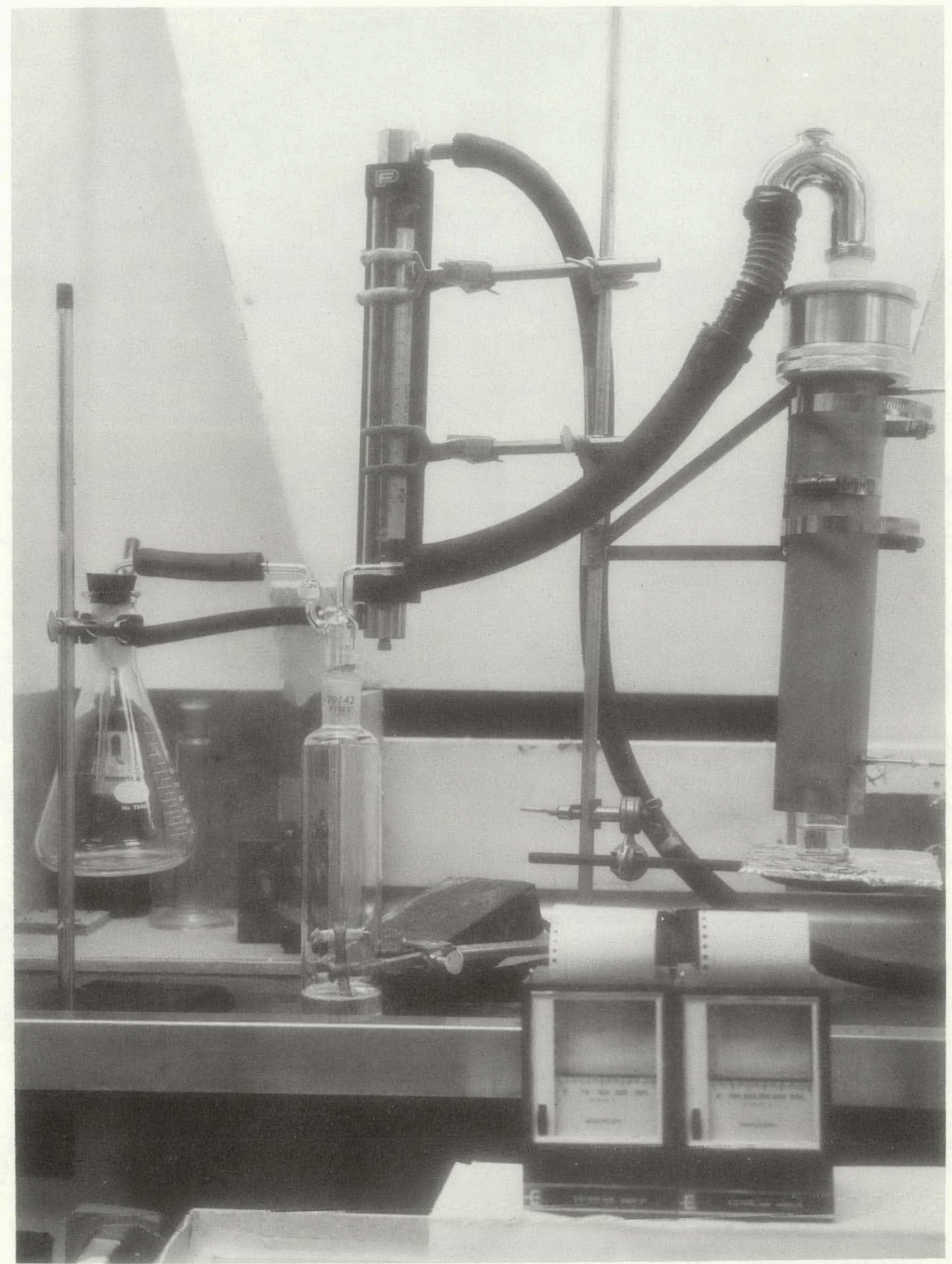

FIGURE $1 \mathrm{a}$

LABORATORY APPARATUS USED IN MEASURING

FRACTIONAI AIRBORNE RELEASE

Neg. No. PNL 732382-6 


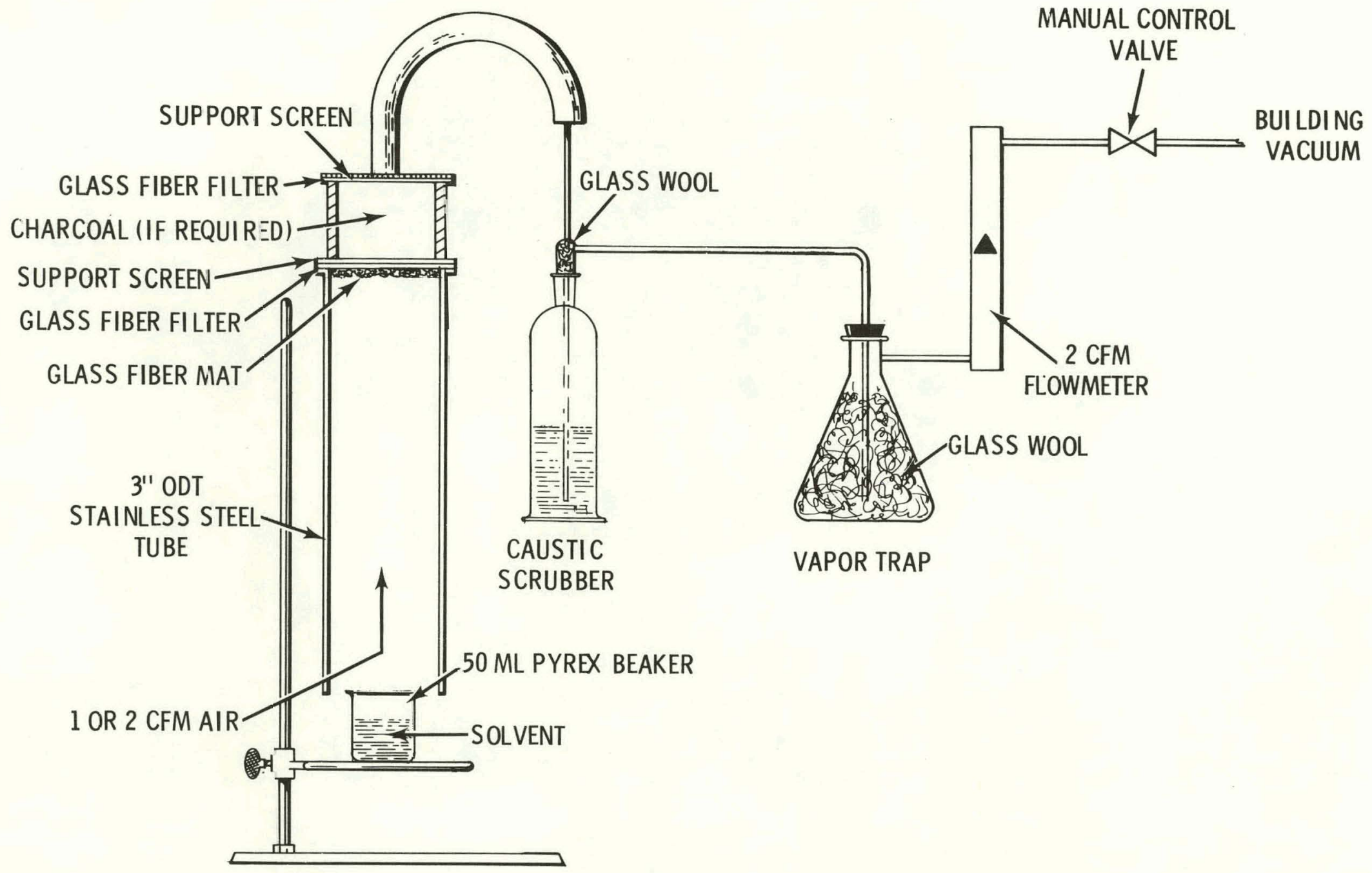

FIGURE $1 \mathrm{~b}$

SCHEMATIC DIAGRAM OF EXPERIMENTAL APPARATUS 
under these conditions were 100 to $120^{\circ} \mathrm{C}$. Other vessels were evaluated in the preliminary studies (aluminum cans and a stainless steel beaker). For these containers heat transfer to the liquid by conduction was high enough to boil the solvent and resulted in extremely smoky burning and flames around the exterior walls of the vessel. Burning in a glass beaker was believed to be more representative of the burning situations anticipated. Air temperatures a few inches over the beaker were typically in the order of $150^{\circ} \mathrm{C}$ with a maximum of $300^{\circ} \mathrm{C}$. Under these conditions, the flame self-extinguished in 42 to 56 minutes leaving from 4 to $9 \mathrm{ml}$ of a thick syrupy liquid. In some experiments, the liquid residue was heated to dryness using a propane torch until the residue was charred (see Figure 2). Temperatures as high as $500^{\circ} \mathrm{C}$ above the liquid and in the burning vapors in the chimney were recorded.

Fractional releases were measured by determining the quantity of the material of interest in the residue, chimney, filter back-up apparatus (a caustic scrubber for all materials except iodine for which a charcoal bed was used). Figure 3 shows the upper portion of the chimney which housed the filter and charcoal bed.

Fractional releases of uranium were determined using the prepared organic solvent alone while trace quantities of ${ }^{137} \mathrm{Cs},{ }^{95} \mathrm{Zr}-\mathrm{Nb},{ }^{144} \mathrm{Ce}-\mathrm{Pr}$ and ${ }^{13{ }^{1}}$ I were mixed singly with the organic solvent in experiments to measure fractional releases of these materials. All uranium samples required processing to place all material in solution. Residual material in the beaker and material deposited in the chimney were washed from the items by successive acetone, water and nitric acid washcs and swabuing. 'l'he collected material was placed into solution using a mixed acid leach. Material collected on the prefilter and filter were warmed using $\mathrm{HF}$ followed by conversion to nitrate by heating to dryness in nitric acid. Recoveries ranged from 66 to 96 percent.

Uranium was analyzed by the UV fluorescence method. The analysis of gamma emitters was by comparative gamma counting. Known amounts of each isotope were pipetted into the various sample matrices used and counted on a gamma spectrometer in close sequence to the analysis of the samples from the burning experiments. The activity in the samples was determined by comparing the counting rate in discrete channels containing the gamma energy peak response of the samples and standard. The only difficulty with this technique encountered was in analysis of the ${ }^{144} \mathrm{Ce}-\mathrm{Pr}$ in residues. The high uranium content of this sample interferred with the accurale evaluation of the low energy, $0.145 \mathrm{mev},{ }^{144} \mathrm{Ce}-\mathrm{Pr}$. 


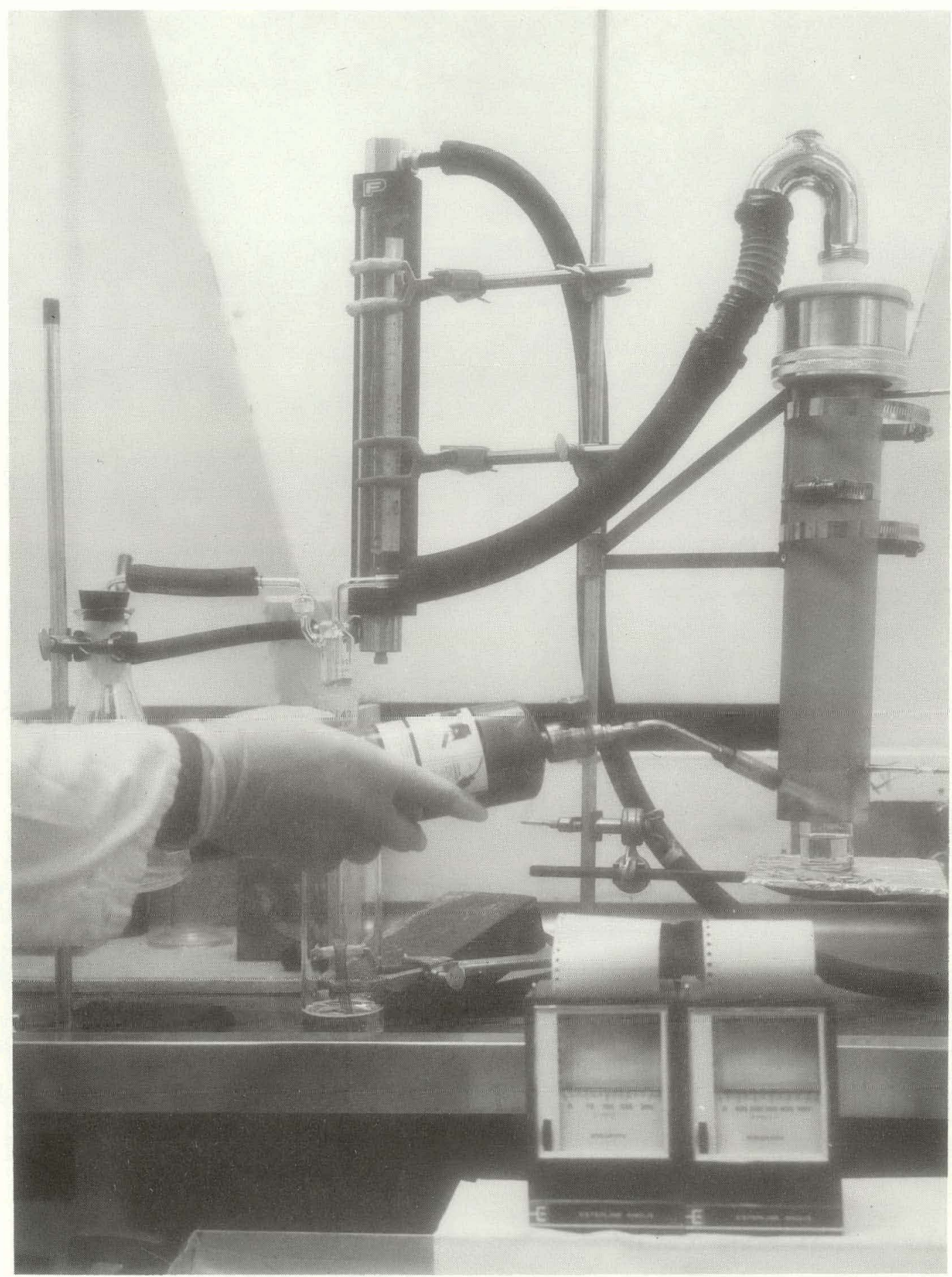

FIGURE 2

HEATING SOLVENT WITH PROPANE TORCH

Neg. No. PNL 732382-7 


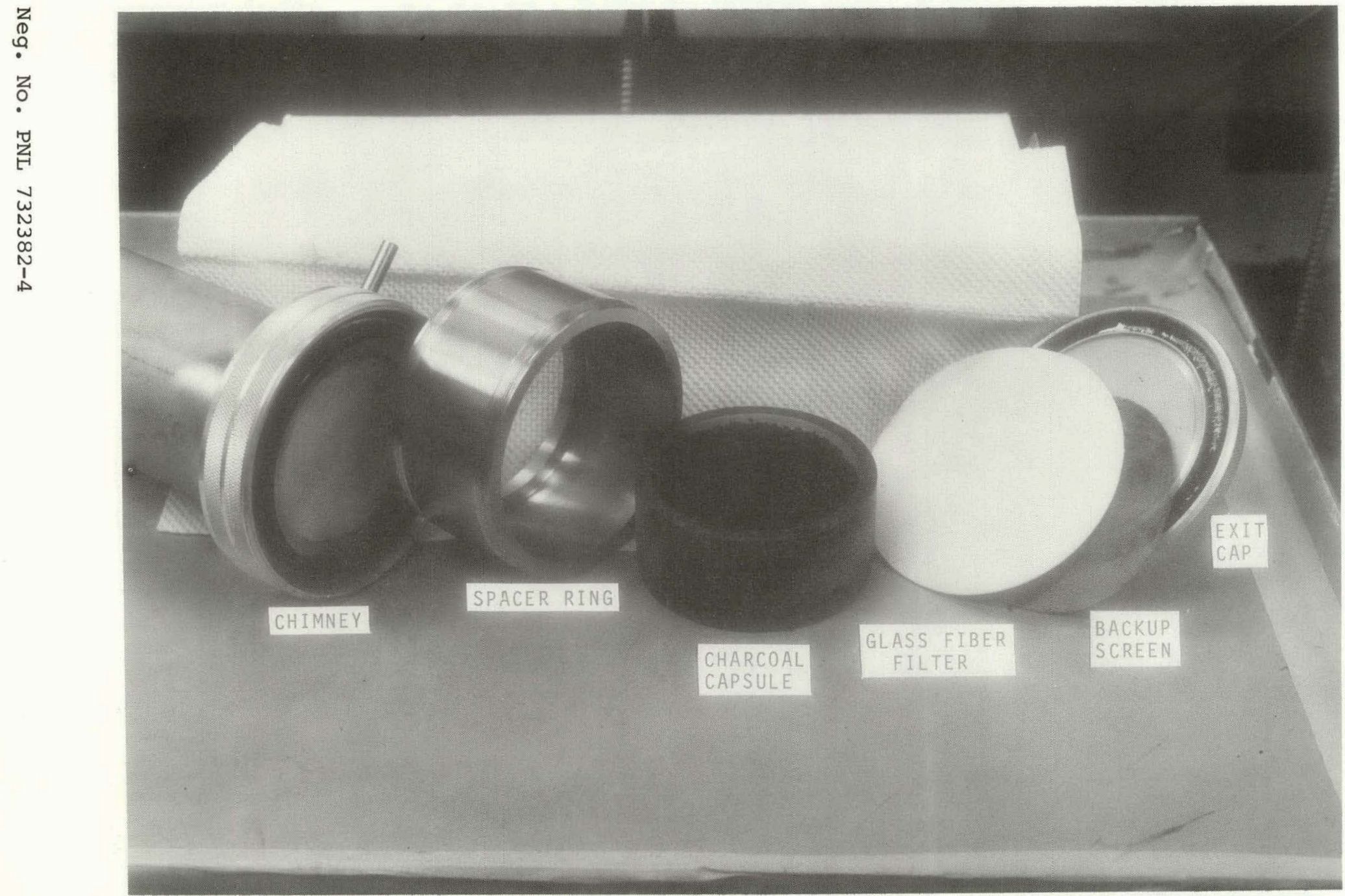

$\infty$

FIGURE 3

AIRBORNE PARTICLES AND IODINE COLLECTOR 


\section{RESULts And Discussion}

The fractional airborne release of the isotopes evaluated was 1 percent or less except for ${ }^{131}$ I. Significant quantities of ${ }^{13 l} I$ were lost up to the time of self-extinguishment (approximately 65 percent). When further external heating to dryness followed the self-sustaining burning period, about 83 percent was released. Since iodine sublimes at $i 84^{\circ} \mathrm{C}$ and methyl iodide boils at $42.5^{\circ} \mathrm{C}$, high releases are not surprising. Higher fractional releases of iodine might be anticipated with longer heating times or higher temperatures. All fractional releases measured are shown in Table $I$.

The fractional release of the remaining materials -- uranium, cesium, cerium, and zirconium -- were low. Cerium appears to be the most readily entrained but considerable variations can be found in the measured release for all materials. The variations are explainable if the release were due to the flaking of salts deposited on the walls of the beaker by capillary action. Uranium tends to remain with the $n$-TBP which is less mobile than the kerosine. Thus, less uranium is available for entrainment and less is released. The fractional release of uranium is an order of magnitude less up to the point of self-extinguishment than for the other elements. Up to the point of extinguishment the TBP appears to be little involved in the burning process. One percent of the liquid used is only $0.25 \mathrm{ml}$, a quantity readily accommodated on the walls of the beaker. That volume of liquid uniformly distributed over the top inch of a $50 \mathrm{ml}$ beaker would produce a film approximately $60 \mu \mathrm{m}$ deep. The particles generated from the salts deposited from such a thin film of liquid would be quite small.

\section{FUTURE WORK}

Engineering scale experiments in the ARHCO, 224-T Fire Test Facility are planned and are being implemented to determine if fractional release vary from those found under laboratory conditions. Two stable isotopes of elements used in the laboratory (cesium and zirconium) will be used as indicators. Analysis will be by atomic absorption spectrometer rather than through use of radioactive tracers. 
TABLE I

FRACTIONAL AIRBORNE RELEASE OF SELECTED ISOTOPES IN 30 PERCENT n-TRIBUTYL PHOSPHATE IN A KEROSINE-TYPE DILUENT DURING COMBUSTION

Element

Uranium ( $270 \mathrm{~g} / 1)$
Cesium ( $0.2 \mathrm{ppm})$
Cerium ( $0.2 \mathrm{ppm})$
Zirconium $(\sim 0.2 \mathrm{ppm})$
Iodine ( $0.2 \mathrm{ppm})$

Uranium (ro $270 \mathrm{~g} / \mathrm{l})$

Iodine ( 0.2 ppm $)$

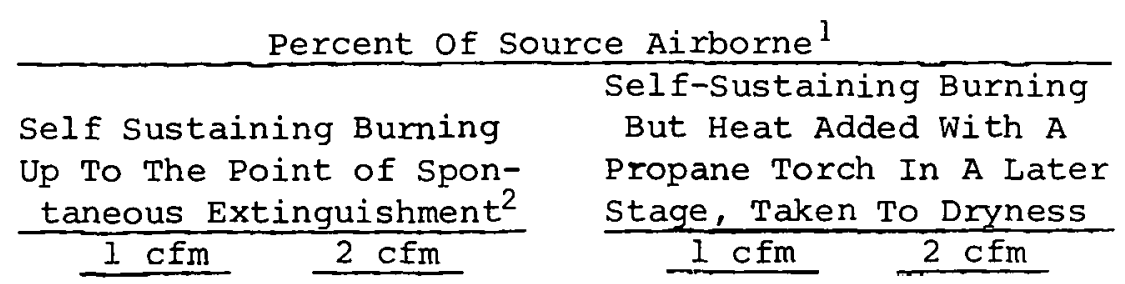

$\begin{array}{ll}0.027 \% & 0.023 \% \\ 0.22 \% & 0.25 \% \\ 0.74 \% & 0.56 \% \\ 0.65 \% & \text { ND } \\ 65.7 \% & 65.3 \%\end{array}$

$0.3 \%$

$0.19 \% \quad 1.0 \%$ *

$0.77 \div 0.71 \%$ *

$0.55 \% 0.24 \%$ *

$81.7 \%$ * $84.3 \%$ *

$82.8 \% *$

$83.3 \% *$

1 Activity measured in all samples except residue.

2 Experiment ended when flame self-extinguished. Usually 5 to $10 \mathrm{ml}$ of liquid remained.

* Percent of total activity collected.

ND Not Detectable 


\section{REFERENCES}

[1] S.M. Stoller and R.B. Richards, Ed. Reactor Handbook, Vol. II, Fuel Processing, Interscience Publishers, New York, 1961 (second edition).

[2] National Fire Codes, Vol. I, Flammable Liquids, National Fire protection Association International, 60 Battery March St., Boston, Mass., 02110.

[3] L.L. Burger. The Flammability of Vapors Above Purex System, HW-40820, General Electric Company, HAPO, Richland, Wash., January 9, 1956.

[4] H.A. Lee. "Fire Protection in Caves, Canyons, and Hot Cells," Proceedings of the 12th AEC Air Cleaning Conforence, Oak Ridge, Tennessee, Aug. 28-31, 1972 .

[5] H.A. Lee. "Fire Protection Test Facility for Cells and Caves," in the Proceedings of the Rocky Flats Symposium on Safety in Plutonium Handling Facilities, CONF-710401, April, 1971, pp 237-247.

[6] H.A. Lee. Semi-Annual Report Program for Fire Protection-Caves, Canyons, and Hot Cells -- May I, 1972 Through October 31, 1972, ARH-2667, Atlantic Richfield Hanford Company, Richland, Wash., Dec. 11, 1972. 


\section{APPENDIX A}

MATERIAL SPECIFICATIONS

Chemical: Normal Paraffin Hydrocarbon (NPH)

CPD Material No.: 669

\section{Purchase Specifications}

a. N-paraffin hydrocarbon

b. $\mathrm{C}_{10}$ to $\mathrm{C}_{14}$ components

c. Aromatics as 1,2,3,4tetrahydronapthalene

d. Iodine number (olefins as wt. $\%$-tetradecene)

e. Alcohol

f. Sp. Gr. 60/60 F

g. Viscosity@ $25^{\circ} \mathrm{C}$

h. Flash Point

i. Interfacial tension between hydrocarbon and $0.1 \mathrm{M} \mathrm{NaOH}$

j. Solids

k. Color
Value Wt.\%

Min. 98 vol.

Min. 99 vol. 옹

Max. 0.2 Wt.\%

$\operatorname{Max} .0 .1$ wt. $\%$

$\mathrm{Zx}-21$

Max. 0.05 wt.\%

$\mathrm{zx}-22$

Max. 0.76

Max. 1.8 centipoises

Min. $70^{\circ} \mathrm{C}$

Min. 12

Dynes/cm

None Visible

colorless
$2 y-10 A$

$z y-9$

$z y-6$

$\mathrm{zy}-22$

Test Requirements Method Frequency

$z y-28 \quad E S$

$z y-28$

ES

ORPE

ORPE

ORPE

ES

ES

ES

ORPE

Visual ES

Visual

ES

NOTE: Vendors whose products meet the above specifications may submit a one-gallon sample for laboratory evaluation of compatibility with plant processing conditions. 
11 AEC Richland office

D.A. Davis (10)

O.J. Elgert

10 ATLANTIC RICHFIELD HANFORD COMPANY

H.A. Lee

45 BATTELLE-NORTHWEST

R.L. Conley

J.J. Fuquay

J.M. Hales

J. Mishima (35)

L.C. Schwendiman

J.M. Selby

C.L. Simpson

Technical Information (3)

Technical Publications 